\title{
PERKEMBANGAN ILMU HUKUM PIDANA KORPORASI DIHUBUNGKAN DENGAN PENDIDIKAN HUKUM BERKELANJUTAN BAGI ADVOKAT
}

\author{
Timbo Mangaranap Sirait \\ Pengacara/Penasehat Hukum \\ email: mangaranaptimotiuslaw@gmail.com \\ disampaikan 5/9/17 - di-review 27/11/17 - diterima 25/12/17 \\ DOI: $10.25123 /$ vej.2684
}

\begin{abstract}
Not only natural persons but also corporations possess the ability to commit crimes. This observation led the Indonesian government to develop policies to prevent and deter those crimes prone to be committed by corporations. A normative juridical research is performed to trace this development. As a conclusion the author argues that any programs of sustainable legal education for advocates should incorporate the subject matter of corporate crimes.
\end{abstract}

Keywords:

advocat; criminal law; corporation; sustainable legal education.

\begin{abstract}
Abstrak
Tidak saja manusia melainkan juga korporasi dalam kenyataan berpotensi melakukan tindak pidana. Kenyataan ini mendorong Negara merancang kebijakan pencegahan dan pemberantasan kejahatan dalam rangka melindungi masyarakat dari ancaman bahaya tindak pidana yang dilakukan korporasi. Penelitian yuridis normatif ini dilakukan dengan tujuan menelusuri perkembangan ini. Sebagai kesimpulan dinyatakan bahwa pendidikan hukum berkelanjutan, khususnya di bidang ilmu hukum pidana, bagi advokat harus mengajarkan hal ihwal kejahatan korporasi.
\end{abstract}

Kata kunci: advokat; ilmu hukum pidana; korporasi; pendidikan berkelanjutan.

\section{Pendahuluan}

Perkembangan dan dinamika serta bentuk tindak pidana oleh korporasi di seluruh dunia semakin beragam, hukum nasional di setiap negara seakan tertatihtatih mengikuti perkembangan kejahatan-kejahatan white collar crime tersebut. Untuk itu setiap negara seperti Indonesia maupun Amerika Serikat berusaha untuk melakukan pembaruan dan perluasan ruang-lingkup dari hukum pidananya untuk menghindari adanya kekosongan hukum. ${ }^{1}$

1 Timbo Mangaranap Sirait, Urgensi Perluasan Pertanggungjawaban Pidana Korporasi Sebagai Manifestasi Pengejawantahan Konstitusi, Jurnal Konstitusi, Mahkamah Konstitusi R.I., Volume 13 Nomor 3, 660, 662 (September 2016). 
Selama kurang lebih seperempat abad berbagai yurisdiksi negara telah merancang berbagai kebijakan tentang dengan cara bagaimana negara dapat mencegah dan menekan tingkat kejahatan serta melindungi masyarakat dari pelaku tindak pidana subjek korporasi. Menurut catatan sejarah, Mahkamah Agung (Suppreme Court) Amerika Serikat melalui putusannya tahun 1886 di Santa Clara County versus Southern Railroad telah menetapkan bahwa korporasi dapat diperlakukan seperti orang (natural person). Sedangkan Indonesia setelah tahun 1945 menyatakan kemerdekaannya, baru tahun 1951 secara tegas menyatakan korporasi sebagai subjek hukum pidana. ${ }^{2}$ Hingga kini telah terdapat lebih kurang 100 hukum pidana korporasi (material) in abstracto berupa undang-undang yang di dalamnya mengatur tentang tindak pidana dengan pelaku korporasi, ${ }^{3}$ yang juga mengakibatkan ilmu hukum pidana korporasi pun turut berkembang.

Walaupun ilmu hukum pidana korporasi dan Peraturan hukum pidana korporasi (material) di Indonesia telah berkembang, yang disebabkan adanya tendensi sosiologis korporasi melakukan tindak pidana yang semakin meresahkan masyarakat, dalam praktiknya hingga akhir tahun 2016 tercatat relatif sangat terbatas (sedikit) korporasi yang berhasil diproses hingga dijatuhi pidana in concreto di pengadilan. Penyidik dan penuntut umum tidak berani dan kesulitan melimpahkan perkara tindak pidana korporasi ke pengadilan akibat keterbatasan kemampuan dalam menyusun dan merumuskan surat dakwaan dalam perkara tersebut, sementara pengadilan pun dalam memutus suatu perkara korporasi sangat tergantung surat dakwaan yang diajukan penuntut umum, yang kemudian membuat ambiguitas advokat ketika melaporkan korporasi yang diduga melakukan tindak pidana ataupun dalam hal membela kliennya

2 Undang-undang R.I., No. 17 Tahun 1951, Penimbunan Barang, jo Undang-undang R.I., No. 1 Tahun 1953, Penetapan Undang-undang Darurat Tentang Penimbunan Barang Sebagai Undangundang, L.N.R.I. No. 4 telah menetapkan korporasi sebagai subjek hukum pidana, dan 4 tahun kemudian ditindaklanjuti lagi dengan Undang-undang Darurat No 7 Tahun 1955, Pengusutan, Penuntutan dan Peradilan Tindak Pidana Ekonomi, L.N.R.I. Tahun 1955 No. 27.

3 Menurut mantan Ketua tim Pokja PERMA Nomor 13 Tahun 2016, Surya Jaya bahwa hasil penelitian kurang lebih ada sekitar 100-an undang-undang yang dapat dipakai untuk menjerat korporasi sebagai pelaku tindak pidana. (hukumonline, "UU ini kerap dipakai aparat dalam Menjerat Korporasi", tersedia di: m.hukumonline.com/berita/baca/lt588548020bfc0/uu-inikerap-dipakai-aparat-dalam-menjerat-korporasi). 
(korporasi) yang didakwa melakukan tindak pidana. Hal ini menciptakan ketidakpastian hukum dan ketidakadilan di masyarakat.

Faktor lain yang menyebabkan terjadinya kesenjangan antara hukum pidana korporasi in abstracto dengan penegakan hukum in concreto tersebut adalah karena belum adanya pengaturan hukum acara pidana korporasi (formil) menyangkut tata cara memidana korporasi pelaku tindak pidana secara holistik. Akibatnya implementasi penegakan pertanggungjawaban pidana pun berjalan secara terkotak-kotak (fragmenter) dan instansi sentris, yang menyebabkan terjadinya inkonsistensi penerapan model pertanggungjawaban dan adanya disparitas sanksi pidana terhadap korporasi.

Perkembangan tersebut, harus diantisipasi oleh Advokat, sebab pada akhir tahun 2016 telah diterbitkan hukum acara pidana korporasi (formil) ${ }^{4}$ mengenai tata cara untuk memidana korporasi (legal/nonlegal person). Diperkirakan mulai tahun 2017 akan semakin banyak korporasi yang dilaporkan sebagai pelaku tindak pidana sesuai dengan hukum pidana korporasi. Terbitnya hukum acara pidana korporasi yang akan menjadi prosedur atau tata cara penanganan perkara tindak pidana oleh korporasi, harus disosialisasikan kepada Advokat melalui pendidikan berkelanjutan, sehingga tidak terjadi malpraktik pada saat advokat mendampingi klien korporasi. Mengingat selama ini asas-asas, teoriteori, kaidah-kaidah, norma-norma hukum pidana yang tersedia, kebanyakan diperuntukkan hanya untuk memidana Orang (natural person) sehingga spesifikasi asas-asas, teori-teori dan kaidah-kaidah lama tersebut belum tentu sesuai untuk subjek hukum korporasi.

Antisipasi oleh advokat menjadi penting, mengingat makna dari terma "advokat" dalam kamus Bahasa Indonesia adalah “...ahli hukum yang berwenang bertindak sebagai penasihat atau pembela perkara dalam pengadilan, juga disebut dengan pengacara", 5 untuk itu dalam perkara tindak pidana korporasi, advokat yang diangkat berdasarkan kuasa yang diberikan oleh kliennya harus memiliki

4 Tanggal 21 Desember 2016 Telah ditetapkan Peraturan Mahkamah Agung R.I., No. 13 Tahun 2016, Tata Cara Penanganan Perkara Tindak Pidana Oleh Korporasi, L.N.R.I. Tahun 2016 No. 2058.

${ }^{5}$ Kamus Bahasa Indonesia 15 (Pusat Perbukuan, Departemen Pendidikan Nasional, Jakarta, 2008). 
keahlian khusus sehingga berwenang bertindak mendampingi korporasi secara objektif.

Kesenjangan hukum pidana in abstracto dengan inconcreto dan adanya disparitas sanksi terjadi dalam beberapa putusan pengadilan terkait korporasi misalnya dalam kasus PT. IM2 dan PT. Kalista Alam. Putusan kasus tersebut bukanlah semata-mata produk tunggal dari hakim, tetapi Advokat juga turut andil memberi kontribusi melalui argumentasi pembelaannya yang mungkin saja kurang sahih (valid) serta tidak memenuhi pandangan objektif ${ }^{6}$ keilmuwan hukum pidana korporasi (corporate criminal legal science) yang telah berkembang, sehingga hakim dengan kewenangan yang dimilikinya memutus perkara secara subjektif 7 , dan atau ditambah fakta persidangan atau dakwaan Jaksa saja, dan mengabaikan argumentasi Advokat yang tidak valid tersebut.

Oleh karena itu, mengingat selama ini sudah banyak peneliti yang mengkritisi secara ilmiah kinerja Lembaga-lembaga Kepolisian, Kejaksaan dan Peradilan dalam penegakan hukum, maka ada urgensinya juga untuk mengotokritisi dan mengkaji peranserta dan kinerja Advokat dan Organisasi Profesi Advokat secara objektif (ilmiah) dalam kapasitas sebagai Lembaga penegak hukum. Khususnya sejauh mana advokat atau calon advokat berhasrat untuk meningkatkan kapabilitasnya pada bidang khusus tertentu ${ }^{8}$ melalui organisasi profesinya, misalnya kemampuan ilmiah advokat dalam mengikuti perkembangan ilmu hukum pidana korporasi (corporate criminal legal science) ${ }^{9}$ yang kelak dapat diterapkan dalam mendampingi klien (korporasi) yang sedang menghadapi kasus tindak pidana.

\footnotetext{
6 Moelyatno memberikan pengertian tentang pandangan "objektif" yaitu menurut ketentuan ilmiah, sehingga boleh diuji dan diteliti kebenarannya oleh siapapun lihat, Moelyatno, Asas-asas Hukum Pidana 13 (Rineka Cipta, Edisi Revisi, Jakarta, 2008).

7 Id, Sedang untuk pandangan yang "subjektif", Moelyatno memberikan pengertian yaitu menurut keinginan atau kehendak sendiri, yang tergantung dari keadaan masing-masing,

8 Undang-undang R.I., No. 18 Tahun 2003, Advokat, L.N.R.I. Tahun 2003 No. 49, Pasal 3 ayat (2) mengatur tentang advokat dapat menjalankan praktiknya dengan mengkhususkan diri pada bidang tertentu.

9 Sejak tahun 1243 korporasi dikenal corporate criminal legal science telah mengalami perkembangan baik secara parsial dan bertahap (evolusioner) hingga perubahan secara mendasar (revolusioner) dalam PERMA Nomor 13 Tahun 2016
} 
Untuk itu, masalah yang akan diangkat dalam tulisan ini adalah berkaitan dengan sejarah perkembangan profesi Advokat dan pertanggungjawaban pidana korporasi secara universal; perkembangan profesi Advokat dan korporasi sebagai subjek hukum pidana di Indonesia secara diakronis dan peran serta tanggungjawab Advokat dalam profesinya sebagai penegak hukum Officium Nobile. Selain itu implikasi kesenjangan hukum In Abstracto dan dampak terhadap pembelaan Advokat atas pidana korporasi In Concreto dan peranserta Advokat sebagai Officium Nobile dalam membela korporasi terduga pelaku tindak pidana Korporasi (Corporate Crimes) dan peranserta Organisasi Profesi Advokat dalam memberikan pendidikan hukum berkelanjutan (Continue Legal Education) bekerjasama dengan Perguruan Tinggi hukum.

\section{Sejarah Perkembangan Profesi Advokat dan Pertanggungjawaban Pidana Korporasi Secara Universal}

Secara historis, dalam pandangan bangsa Romawi, hukum itu tidak berasal dari "atas" (dunia supranatural, dewa-dewi), melainkan produk karya cipta manusia. Namun meskipun demikian, mereka menempatkan hukum di atas manusia dalam arti dipandang memiliki atau diberi kekuatan objektif, dan dengan itu berlaku secara umum sehingga harus dihormati dan dipatuhi oleh semua orang termasuk orang-orang yang membentuknya dan yang mengemban kekuasaan pemerintahan pada umumnya, ${ }^{10}$ antara lain mulai dari Raja dan para pembantunya, hakim, yuris, advokat, dan masyarakat pada umumnya.

Pada masa ancient regime Romawi korporasi belum dikenal dan orang (natural person) masih menjadi satu-satunya subjek hukum. Asas Nullum delictum nulla poena sine praevia lege dan asas legalitas belum dikenal. Tetapi masa tersebut ada dikenal kejahatan yang dinamakan "kejahatan-kejahatan yang tidak disebut dalam undang-undang" (criminal extra ordinaria) di antaranya yang terkenal "perbuatan jahat, durjana" (crimina stellionatus) ${ }^{11}$ yang tidak ditentukan

\footnotetext{
${ }^{10}$ Bernard Arief Sidharta, et.al. Pengemban Hukum Teoritis, Refleksi Atas Konstellasi Disiplin Hukum 9, (Logoz Publishing, Bandung, 2014).

11 Lihat, Moeljatno, Supra no. 5, hlm. 26.
} 
bentuknya berupa apa, sehingga memungkinkan seorang Raja yang berkuasa untuk menggunakan hukum pidana secara sewenang-wenang menurut kehendak hatinya terhadap seseorang.

Akan tetapi masa Romawi kuno profesi Advokat telah dikenal dan digelari profesi yang mulia atau "Officium Nobile" sedangkan terhadap pengembannya disebut sebagai "Orator"12 atau secara teknis nama yang diberikan terhadap orang yang berpraktik di pengadilan sebagai "Patroni Causarum" atau singkatnya "Patroni"13 yang kini dikenal sebagai Advokat. Advokat disebut "Officium Nobile" karena kerelaannya untuk memperjuangkan nilai-nilai kemanusiaan dan tegaknya hukum dan keadilan serta melawan kesewenang-wenangan penerapan ketentuan "kejahatan-kejahatan yang tidak disebut dalam undang-undang" (criminal extra ordinaria) oleh penguasa, walau tidak mengharapkan imbalan dari masyarakat yang sedang menghadapi masalah hukum tersebut.

Cicero (Marcus Tullius Cicero) adalah salah satu orator yaitu advokat yang memiliki ketrampilan handal dalam retorika, filsafat, beracara, dan juga Negarawan Romawi Kuno, ia piawai dalam berbicara (berpidato) di hadapan umum, dan seorang yuris yang handal dalam hukum untuk mendakwa dan membela baik di pengadilan maupun di Majelis Tinggi.

Kerelaan seorang Advokat terlibat menegakkan keadilan dan menolak kesemena-menaan "criminal extra ordinaria" walau tanpa mengharapkan imbalan (prodeo), telah mengilhami William Shakespeare's dengan quote nya yang kontroversial dari William Shakespeare's pada Henry VI Part II, act IV, Scene II, Line 73 yang mengatakan "The first thing we do, let's kill all the lawyers...", yang kurang lebih maksudnya dalam cerita tersebut, bahwa hal pertama yang harus dilakukan oleh seorang penguasa agar bebas melakukan perbuatan melawan

\footnotetext{
12 Orator (latin) seperti Cicero (Marcus Tullius Cicero) adalah salah satu Orator yang memiliki ketrampilan handal dalam retorika, filsafat, dan Pengacara, juga Negarawan Romawi Kuno "who accused themselves to public speaking, either in the popular assemblies or in the court of law"(lihat, William Forsyth, History of Lawyers, Ancient and Modern 80-81 (Estes \& Lauriat, Boston, Washington Street, 1875)

13 Patroni Causarum" atau singkatnya "Patroni" adalah pihak yang berpraktek di pengadilan dan pihak yang mewakili kliennya, Id hlm. 81.
} 
hukum dan melawan konstitusi sehingga dapat melanggengkan jalan menuju kekuasaan yang otoriter adalah dengan "membunuh" semua Advokat.

Sejarah mencatat instabilitas internal akibat banyaknya faksi-faksi dan anarki militer, yang kemudian menyebabkan runtuhnya Romawi hingga hampir seluruh Eropa terjadi kekacau-balauan, dan kemudian agama nasrani pun berkembang dan pengaruh Gereja mendominasi Eropa di masa kegelapan (dark ages) hingga masa pra renaisance.

Hingga kini berbagai peristilahan diberikan kepada profesi Advokat, antara lain seperti di Amerika sebagai Lawyer, di Inggris Barrister dan Solicitoir, di Singapura Advokat, di Belanda sebagai Advokat dan Procureur.

Demikian juga halnya dengan sejarah awal perkembangan Korporasi global, yang mulai dikenal dengan dibentuknya Dewan Gereja oleh Paus Innocent IV (1243-1254) sebagai subjek hukum perdata dan memaklumatkan prinsip Societas delinquere non potest yang tidak memperkenankan adanya suatu peradilan pidana bagi korporasi. Hal itu sebagaimana dikatakan oleh Dominik Brodowski, Manuel E.M. de la Parra, dan Klaus Tiedemann yang mengatakan ${ }^{14}$ :

“...Societas delinquere non potest is clearly on its way out.. this principle consecrated by Pope Innocent IV originally aimed at preventing the papal excommunication of civil or business corporations, cities and legal entities for offense committed by one of its members but its no longer a dogma in secularized and enlighted criminal justice, and it does not provide a constitutionally binding barrier to corporate criminal liability".

Dalam artian, bahwa kini prinsip Societas delinquere non potest pada masa modern jelas sudah ditinggalkan. Paus Innocent IV pada awalnya menujukan maklumat tersebut untuk mencegah pengucilan terhadap korporasi sipil atau bisnis, kota dan badan hukum Kepausan (Dewan Gereja) atas pelanggaran yang mungkin dilakukan oleh salah satu anggotanya. Namun Societas delinquere non potest kini bukan lagi dogma yang dianut dalam sistem peradilan sekuler, serta

\footnotetext{
14 Dominik Brodowski, et.al., Requlating Corporate Criminal Liability, Springer, Switzerland, 2014, hlm 2
} 
tidak lagi menjadi asas hukum yang dapat menghalangi dan mengikat pertanggungjawaban pidana korporasi.

Pengaruh adagium "Societas delinquere non potest " lama mempengaruhi sistem hukum pidana dunia termasuk dalam Pasal 59 KUHP (WvS) Indonesia, sehingga perkara korporasi selalu bersifat perdata dan hampir tidak ada advokat menggugat (memperkarakan) korporasi dalam ranah pidana. Walaupun kemudian mengingat tendensi korporasi melakukan pidana semakin tinggi, maka berbagai yurisdiksi hukum negara mulai menerapkan pertanggungjawaban pidana terhadap korporasi.

Sebagaimana dikatakan Dominik Brodowski, Manuel E.M. de la Parra, dan Klaus Tiedemann, “...Tren dunia saat ini terhadap pertanggungjawaban pidana korporasi berasal dari negara-negara common law, terutama di AS, di mana Mahkamah Agung (Suppreme Court) menyatakan dalam keputusannya pada tahun 1886 di Santa Clara County versus Southern Railroad bahwa sebuah perusahaan dapat diperlakukan seperti orang biasa (natural person)",15 telah menjadi salah satu contoh putusan pengadilan dalam yurisdiksi AS yang kelak membuat kebijakan dan ilmu hukum pidana korporasi pun semakin berkembang.

20 tahun kemudian pada tahun 1909 Mahkamah Agung (Suppreme Court) mengeluarkan Putusan bersejarahnya perihal New York Central versus Hudson River Railroad Co., yang melahirkan konsep "badan hukum dapat dipidana (Societas delinquere potest)". Dari sejarahnya, pertanggungjawaban pidana korporasi secara sederhana adalah merupakan reaksi atas semakin pentingnya kedudukan entitas hukum terutama di bidang ekonomi, yang menyebabkan makin banyaknya kejahatan dengan pelaku badan hukum, atau kejahatan yang dilakukan untuk keuntungan (keuangan) badan hukum. ${ }^{16}$ Selanjutnya pengaruh di Amerika dan berbagai negara lainnya, telah membuat berbagai yurisdiksi negara sepakat untuk memidana korporasi yang tidak lagi hanya terlihat dalam sistem peradilan pidana nasional, tetapi menjadi trend pemidanaan korporasi di tataran

15 Id hlm. 2.

16 Id. 
internasional (global) dengan asas universal di mana advokat terlibat di dalamnya untuk melakukan pembelaan di peradilan.

\section{Perkembangan Profesi Advokat dan Korporasi Sebagai Subjek Hukum Pidana di Indonesia secara diakronis}

Hukum pidana korporasi dalam KUHP17 dan sistem hukum pidana Indonesia di satu sisi, serta keberadaan Advokat di Indonesia di sisi lain yang berjalan secara paralel dan tidak dapat dipisahkan dari sejarah perjalanan bangsa Indonesia yang merupakan peninggalan penjajahan Hindia Belanda. Advokat adalah sebuah peristilahan yang dapat ditemukan di dalam dunia sistem peradilan di Indonesia yang dahulu dikenal dengan berbagai penyebutan antara lain seperti advokat, procereur, pembela, penasehat hukum, pengacara, pokrol bambu, dan lawyer.

Menurut sejarah advokat di Indonesia, organisasi advokat di Indonesia bermula pada masa kolonialisme. Pada masa itu, jumlah advokat masih sedikit dan keberadaannya terbatas pada kota-kota besar yang memiliki Landraad dan Raad van Justitie. Mereka bergabung dalam organisasi advokat yang dikenal sebagai Balie van Advocaten. Di awal orde baru para advokat Indonesia memiliki banyak organisasi advokat sebagai warisan dari banyaknya Balie van Advocaten yang dibentuk pada masa sebelumnya. ${ }^{18}$ Kemudian, setelah kemerdekaan 1945 semangat untuk tetap bersatu dan saling menghormati sebagai sesama rekan advokat secara demokratis tetap terjalin dan terpelihara dengan baik, walaupun para advokat bernaung di organisasi berbeda karena terbentuknya berbagai Organisasi Advokat sebagai perlambang dari sistem multi bar association.

\footnotetext{
17 Undang-undang R.I. No. 1 Tahun 1946 Jo. Undang-undang R.I. No. 73 Tahun 1958 Tentang Menyatakan Berlakunya UU No. 1 Tahun 1946 R.I. Tentang Peraturan Hukum Pidana Untuk Seluruh Wilayah R.I. dan Mengubah Kitab Undang-undang Hukum Pidana L.N.R.I. 1958 No. 127 Tambahan L.N.R.I. No. 1660)Pasal 59 KUHP masih memegang prinsip "Societas delinquere non potest" bahwa korporasi tidak dapat dipidana dan pertanggungjawabannya dibebankan kepada orang (pengurus).

18 Binzaid Kadafi, et. al., Pembentukan Organisasi Advokat Indonesia: Keharusan atau Tantangan? Pusat Studi Hukum \& Kebijakan Indonesia atas kerjasama dengan The Asia Foundation, Jakarta, 2004, hlm 1.
} 
Lahirnya Undang-undang Nomor 18 Tahun 2003 Tentang Advokat, sebagaimana disyaratkan dalam Pasal $28^{19}$ menjadi era lahirnya wadah tunggal profesi Advokat (sistem single bar association) dengan berdirinya PERADI (Perhimpunan Advokat Indonesia) yang digagas oleh tujuh organisasi profesi Advokat yang tergabung dalam Komite Kerjasama Advokat Indonesia (KKAI) yaitu Ikatan Advokat Indonesia (IKADIN), Asosiasi Advokat Indonesia (AAI), Ikatan Penasehat Hukum Indonesia (IPHI), Asosiasi Konsultan Hukum Indonesia (AKHI), Himpunan Konsultan Hukum Pasar Modal (HKPM), Serikat Pengacara Indonesia (SPI), dan Himpunan Advokat \& Pengacara Indonesia (HAPI).

Melalui Pasal 5 ayat (1) 20 Undang-undang Nomor 18 Tahun 2003 Tentang Advokat ditegaskan bahwa Advokat merupakan salah satu penegak hukum yang sejajar kedudukannya dengan penegak hukum lainnya. Walaupun notabene kedudukannya sesama penegak hukum, tetapi posisinya berada pada pihak yang berbeda-beda, di mana Polisi dan Jaksa mewakili negara, Hakim mewakili Tuhan Yang Maha Esa sehingga ketiganya ditempatkan berada dalam struktur negara, sedangkan Advokat karena mewakili masyarakat berada di luar struktur pemerintah.

Era single bar association dapat bertahan selama 12 tahun (2003-2015), dan runtuh tahun 2015 karena ditenggarai tidak mencerminkan nilai-nilai historis dan dianggap telah memperlakukan Advokat secara diskriminatif. Seluruh Pengadilan Tinggi pun diberi kewenangan oleh Mahkamah Agung mengangkat sumpah para Advokat dari semua organisasi Advokat (PERADI, PERADIN, IKADIN, KAI dan lain-lain). Akan tetapi era multi bar yang dimulai sejak terbitnya Surat Ketua Mahkamah Agung Republik Indonesia Nomor 73/KMA/HK.01/IX/2015 tertanggal 25 September 2015 bagaikan dua sisi mata uang yang membawa dampak positif dan dampak negatif, walaupun harus tetap diakui bahwa dengan

\footnotetext{
${ }^{19}$ Supra no. 7, pada Pasal 28 ayat'(1): “Organisasi Advokat merupakan satu-satunya wadah profesi Advokat yang bebas dan mandiri yang dibentuk sesuai dengan ketentuan Undang-undang ini dengan maksud dan tujuan untuk meningkatkan kualitas profesi Advokat. (2)Ketentuan mengenai susunan Organisasi Advokat ditetapkan oleh para Advokat dalam Anggaran Dasar dan Anggaran Rumah Tangga".

${ }^{20}$ Id pada Pasal 5 ayat (1): "Advokat berstatus sebagai penegak hukum bebas dan mandiri yang dijamin oleh hukum dan peraturan perundang-undangan”.
} 
segala kelebihan dan kekurangannya telah membawa perubahan dalam dunia profesi advokat Indonesia. Dilihat dari segi kelebihannya atau dampak positifnya antara lain Surat Ketua Mahkamah Agung tersebut telah mengembalikan nilainilai demokratis multi bar, dan telah menghilangkan sikap diskriminatif yang tidak sesuai sejarah perjalanan advokat Indonesia, serta mengembalikan hak hidup dan hak untuk beracara yang terampas oleh single bar dalam membela kliennya di pengadilan. Dilihat dari segi kekurangannya atau dampak negatifnya, antara lain ternyata organisasi-organisasi advokat yang ada, belum siap mengantisipasi surat Ketua Mahkamah Agung tersebut, sehingga dapat membekali advokat anggotanya seperti yang diharapkan oleh Undang-undang, dengan pendidikan berkelanjutan yang sesuai dengan standar yang ditentukan oleh sistem pendidikan nasional dan kerangka kualifikasi nasional Indonesia.

Paralel dengan perkembangan dunia Advokat sebagaimana di atas, setelah 6 tahun Indonesia merdeka dari penjajahan, indikasi bahwa korporasi dapat melakukan tindak pidana sebenarnya sudah terdeteksi oleh para pembuat undang-undang, sehingga pada tahun 1951 para "law maker" secara bertolakbelakang (contrario) dengan Pasal 59 KUHP, sudah menerbitkan aturan hukum pidana terkait korporasi sebagai langkah represif menciptakan efek jera dalam mengatasi korporasi yang melakukan tindak pidana dan menyatakan secara tegas sebagai subjek hukum pidana.

Namun selama pasang surut perkembangan dunia profesi advokat (19452016) tersebut, masih relatif sedikit korporasi yang melakukan tindak pidana diproses di pengadilan akibat pengaruh kosongnya pengaturan hukum acara pidana bagi korporasi sebagai subjek yang melakukan tindak pidana. Walau secara "de jure" terdapat banyak undang-undang yang menempatkan korporasi sebagai subjek tindak pidana, tetapi akibat paradigma lama penegakannya yang terkotak-kotak (fragmenter) telah menciptakan ambiguitas dalam tatacara pendampingan korporasi oleh Advokat. Selain bahwa secara "de facto" korporasi tetap saja ada yang melakukan pelbagai tindak pidana (corporate crime), bahkan menjadi tempat menyembunyikan harta kekayaan hasil pidana yang merugikan negara dan masyarakat. Dengan sangat terbatas korporasi yang berhasil diminta 
pertanggungjawabannya serta diproses di peradilan, maka diterbitkanlah Peraturan Mahkamah Agung (PERMA) Nomor 13 Tahun 2016 Tata Cara Penanganan Perkara Tindak Pidana Oleh Korporasi, sebagai paradigma baru sistem peradilan pidana untuk mengendalikan kejahatan korporasi.

\section{Peran dan Tanggungjawab Advokat Dalam Profesinya Sebagai Penegak Hukum Officium Nobile}

Terbitnya Peraturan Mahkamah Agung (PERMA) Nomor 13 Tahun 2016 tentang Tata Cara Penanganan Perkara Tindak Pidana Oleh Korporasi, akan menjadi era baru tindak pidana korporasi. Peranserta advokat diperkirakan akan semakin meningkat karena akan semakin banyak korporasi yang diproses di peradilan pidana atas perbuatannya, sehingga membutuhkan kepiawaian ilmiah advokat dalam menegakkan hukum dan keadilan dalam perkara pidana korporasi tersebut.

Sebagaimana diketahui, Advokat adalah orang yang berprofesi memberi jasa hukum, baik di dalam maupun di luar pengadilan yang memenuhi persyaratan berdasarkan Undang-undang. ${ }^{21}$ Oleh karena itu, seorang Advokat yang di satu pihak bertindak sebagai seorang anggota penegak hukum dan juga penegak sistem hukum dalam kapasitas mewakili hak dan kepentingan kliennya, tetapi di pihak lain juga merupakan warganegara yang memiliki tanggungjawab khusus untuk tegaknya keadilan. Selain itu, profesi Advokat juga disebut sebagai jabatan yang mulia (officium nobile), disebut mulia karena seorang advokat harus bertindak dengan segala upaya (all-out) membela kliennya. Ia bertindak sebagai perwakilan (representative) dari klien, sebagai konsultan, penasehat, sebagai pengacara, sebagai negosiator, dan sebagai eksaminator atas perkara klien.

Peran Advokat juga “...sebagai perwakilan dari klien, untuk mana seorang Advokat yang mewakili kliennya melakukan berbagai fungsi. Sebagai Penasehat, seorang advokat menyampaikan ke klien agar memahami hak dan kewajiban hukum klien serta menjelaskan bagaimana maksudnya dalam praktek. Sebagai

21 Id pada Pasal 1 Ayat 1. 
Pengacara, seorang Advokat dengan tekun menyatakan posisinya dalam sistem peradilan. Sebagai negosiator, seorang Advokat mencari hasil yang menguntungkan terhadap klien tetapi konsisten dengan syarat ketentuan menurut hukum. Sebagai Evaluator, seorang Advokat bertindak dengan mengkaji kasus hukum klient dan melaporkannya terhadap klien atau yang lain. ${ }^{22}$

Mengenai tugas utama seorang advokat, Soemarno P. Wirjanto secara garis besar dapat menjabarkan sebagai berikut.:23 a) Sebagai procurator, yaitu mewakili dan membantu klien di dalam segala pekerjaan yang diperlukan untuk mempersiapkan perkara pengadilan sehingga siap untuk diputus oleh hakim; $b$ ) Sebagai "pleader" atau "pleiter", yaitu mengucapkan pledooi, presentasi fakta-fakta, argumentasi hukum, sehingga hakim dapat mendapatkan pandangan mengenai fakta-fakta mengenai suatu perkara; dan c) Sebagai juris-consult, memberi nasihat hukum di luar peradilan, membantu dengan atau membuat akta-akta hukum, perdamaian hukum dan lain-lain.

Adapun fungsi penting advokat sebagai pembela ialah: ${ }^{24}$ a) Melindungi hak-hak para pencari keadilan diperlakukan di luar kemanusian; b) Untuk dapat segera diperiksa dan diadili jangan sampai berlarut-larut berkepanjangan tanpa adanya kepastian hukum, dan c) Diusahakan hak-hak para pencari keadilan sebagaimana yang telah diberikan oleh undang-undang telah diperhatikan dan tidak dilalaikan baik oleh aparat penegak hukum dan juga aparat negara. Terakhir dalam mendampingi tersangka atau terdakwa baik pada tingkat pemeriksaan penyidikan, penuntutan maupun pada pemeriksaan dalam sidang pengadilan selalu berusaha untuk memberikan perlindungan hukum sebagaimana yang diberikan oleh undang-undang.

\section{Implikasi Kesenjangan Hukum In Abstracto dan Dampaknya Terhadap Pembelaan Advokat Pada Pidana Korporasi In Concreto}

22 Lihat, Stephen Gillers, et.al., Regulation of Lawyer, Wolter Kluwer, New York, 2017, hlm. 35.

${ }^{23}$ Djoko Prakoso, Kedudukan Justisiabel di dalam KUHAP, Ghalia Indonesia, Jakarta, 1986, hlm 38.

${ }^{24}$ Abdussalam \& DPM Sitompul, Sistem Peradilan Pidana, Restu Agung, Jakarta, 2007, hlm 370. 
Adanya kesenjangan norma hukum in abstracto yang menjadi acuan bagi advokat dalam pembelaannya, dengan perkembangan sosiologis kejahatan korporasi yang makin beragam, serta didukung dengan tidak adanya sistem terpadu (integrated system) prosedur penegakan pertanggungjawaban pidana korporasi in concreto, menyebabkan sedikit korporasi pelaku tindak pidana yang diproses pidana hingga ke pengadilan.

Demikian juga perkara tindak pidana korporasi yang sudah putus di pengadilan ada juga yang kurang dapat dinalar secara hukum. Misalnya dalam perkara tindak pidana korporasi PT Kalista Alam (PT KA) dimana Mahkamah Agung menolak banding PT KA. ${ }^{25}$ Dalam kasus tersebut pertanggungjawaban pidana korporasi dilakukan dengan "gugatan Perdata dengan memakai Pasal Pidana". Dalam kasus tersebut PT. KA, digugat dan dihukum secara Perdata tapi mempergunakan Pasal Pidana, korporasi tersebut dituntut melakukan tindak pidana membuka lahan perkebunan dengan cara membakar, dan bersesuaian dengan ketentuan pidana Pasal 69 ayat (1) huruf H di dalam Undang-Undang No. 32 tahun 2009 tentang Perlindungan dan Pengelolaan Lingkungan Hidup.

Kasasi PT. KA ditolak oleh Mahkamah Agung26 dan divonis untuk membayar kerugian sejumlah Rp. 366 Miliar atas tindak pidana membakar lahan tersebut, untuk memulihkan lahan gambut seluas 1.000 hektar yang rusak akibat tindak pidana korporasi tersebut.

Putusan Mahkamah Agung terhadap korporasi PT. Kalista Alam tersebut telah menciptakan ketidak pastian hukum karena Hakim Mahkamah Agung

\footnotetext{
${ }^{25}$ Seminar Nasional, Menjerat Korporasi Dalam Pertanggungjawaban Hukum, Dalam Rangka Peringatan HUT IKAHI ke-64, IKAHI, Hotel Mercure Ancol Jakarta, 21 Maret 2017 (tidak dipublikasi).

26 PT Kalista Alam (...) adalah perusahaan sawit di Kecamatan Darul Makmur, Kabupaten Nagan Raya, Nangroe Aceh Darussalam. Perusahaan yang bergerak di bidang perkebunan dan perindustrian ini terbukti membakar lahannya sendiri. Dalam vonis Mahkamah Agung yang diputuskan pada tanggal 28 Agustus 2015 atas nomor perkara 651 K/PDT/2015 menyatakan terdakwa PT Kalista Alam yang diwakili oleh Subianto Rusid selaku Direktur PT Kalista Alam telah terbukti melakukan pembakaran lahan. PT Kalista Alam terbukti melanggar Pasal 69 ayat (1) huruf H Undang-Undang No. 32 tahun 2009 tentang Perlindungan dan Pengelolaan Lingkungan Hidup yang dilakukan berlanjut juncto Pasal 64 ayat (1) Kitab Undang-Undang Hukum Pidana (KUHP). Putusan tersebut juga menyatakan bahwa untuk memulihkan lahan gambut yang rusak seluas 1.000 hektar, PT Kalista Alam harus membayar kerugian sejumlah Rp. 366 Miliar lebih atas perbuatan mereka, Supra no. $24 \mathrm{hlm}$. 34.
} 
memutus perkara kasasi Perdata tersebut dengan membuat penjatuhan putusan melebihi apa yang diminta undang-undang (Ultra Petita), yaitu menjatuhkan sanksi perdata korporasi dengan memakai Pasal pidana dalam Undang-undang Perlindungan dan Pengelolaan Lingkungan Hidup.

Korporasi tersebut dihukum melebihi ketentuan sanksi pidana yang diatur dalam Pasal 108 yang berbunyi "Setiap orang yang melakukan pembakaran lahan sebagaimana dimaksud dalam Pasal 69 ayat (1) huruf h, dipidana dengan pidana penjara paling singkat 3 (tiga) tahun dan paling lama 10 (sepuluh) tahun dan denda paling sedikit Rp3.000.000.000,00 (tiga miliar rupiah) dan paling banyak Rp10.000.000.000,00 (sepuluh miliar rupiah)".

Menurut Undang-undang Perlindungan dan Pengelolaan Lingkungan Hidup terdapat tiga upaya penegakan hukum yang dapat dilakukan yaitu; upaya diluar jalur pengadilan, upaya jalur pengadilan Perdata, dan terakhir upaya jalur hukum pengadilan pidana. Masing-masing upaya penegakan tersebut memiliki domain atau yurisdiksi yang berbeda. Jika pertanggungjawaban korporasi tersebut dilakukan secara Perdata maka seharusnya pasal yang diterapkan adalah Pasal $90^{27}$ dan bukan ketentuan Pidana dalam Pasal 69 ayat (1) huruf H, dan jika Pasal 69 ayat (1) huruf H diterapkan kepada PT. Kalista Alam dalam yurisdiksi hukum pidana maka seharusnya hanya diberi sanksi pidana denca maksimum Rp. 10 miliar dan bukan Rp. 366 miliar.

Di dalam putusan tersebut dikatakan, kedudukan hukum Penggugat antara lain, bahwa Pemerintah, dalam hal ini instansi yang bertanggung jawab dalam bidang lingkungan hidup diberikan kewenangan oleh undang-undang untuk melakukan upaya hukum guna menuntut ganti rugi serta dilakukannya tindakan tertentu terhadap usaha dan/atau kegiatan yang telah menyebabkan perusakan dan/atau pencemaran lingkungan hidup melalui gugatan perdata. Hak Pemerintah tersebut sebagaimana diatur dalam Pasal 90 Undang-Undang Nomor 32 Tahun

\footnotetext{
27 Lihat, Undang-Undang No. 32 tahun 2009, Perlindungan dan Pengelolaan Lingkungan Hidup, L.N.R.I. Tahun 2009 No. 140, Pasal 90 ayat (1): "Instansi pemerintah dan pemerintah daerah yang bertanggung jawab di bidang lingkungan hidup berwenang mengajukan gugatan ganti rugi dan tindakan tertentu terhadap usaha dan/atau kegiatan yang menyebabkan pencemaran dan/atau kerusakan lingkungan hidup yang mengakibatkan kerugian lingkungan hidup".
} 
2009 tentang Perlindungan dan Pengelolaan Lingkungan Hidup, selanjutnya disebut "Undang-Undang Lingkungan Hidup. ${ }^{28}$

Jika konsisten diterapkan maka model pertanggungjawaban pidana PT. Kalista Alam ini adalah "Korporasi sebagai pembuat dan juga sebagai yang bertanggung jawab", sebagai penjelasan dari model tersebut “...Menurut Schaffmeister, D, N. Keijzer, E. PH. Sutorius yang disitasi Dwidja Priyatno, dalam Model ini, korporasi sebagai pembuat dan juga sebagai yang bertanggung jawab motivasinya adalah dengan memperhatikan perkembangan korporasi itu sendiri, yaitu bahwa ternyata untuk beberapa delik tertentu, ditetapkannya pengurus saja sebagai dapat dipidana ternyata tidak cukup. Dalam delik-delik ekonomi bukan mustahil denda dijatuhkan sebagai hukuman kepada pengurus dibandingkan dengan keuntungan yang telah diterima oleh korporasi dengan melakukan perbuatan itu, atau kerugian yang ditimbulkan dalam masyarakat, atau yang diderita oleh saingan-saingannya, keuntungan dan atau kerugian-kerugian itu adalah lebih besar daripada denda yang dijatuhkan sebagai pidana. Dipidananya pengurus tidak memberikan jaminan yang cukup bahwa korporasi tidak sekali lagi melakukan perbuatan yang telah dilarang oleh undang-undang. Ternyata dipidananya pengurus saja tidak cukup untuk mengadakan repressi terhadap delik-delik yang dilakukan oleh atau dengan suatu korporasi. Karenanya diperlukan pula untuk dimungkinkan memidana korporasi, dan pengurus atau pengurus saja. ${ }^{29}$

Demikian juga putusan Nomor 787/K/Pid. Sus/2014 yang menghukum korporasi PT. Indosat Mega Media (IM2) membayar ganti kerugian atas perbuatan IA selaku Direktur Utama sebesar Rp. 1.358.343.346.674,- (Satu triliun tigaratus limapuluh delapan milyar tigaratus empatpuluh tiga juta tigaratus empat puluh enam ribu enam ratus tujuhpuluh empat). ${ }^{30}$ Penegakan Pertanggungjawaban Pidana korporasi pada kasus ini dirasa tidak mencermin rasa keadilan di mana "pengurus sebagai pembuat dan pengurus serta korporasi

\footnotetext{
28 Putusan Mahkamah Agung R.I. Nomor 651 K/Pdt/2015, tanggal 28 Agustus 2015.

${ }^{29}$ Supra no. 24 pada 10.

30 Mahkamah Agung Republik Indonesia, Putusan Nomor 787/K/Pid. Sus/2014, tanggal dibacakan 10 Juli 2014.
} 
bertanggungjawab". Korporasi berhasil dipidana tetapi tidak diberi kesempatan untuk membela dirinya pada proses penyidikan dan pemeriksaan di pengadilan, sehingga telah berkesan menciptakan ketidakadilan terhadap korporasi.

Selama proses pemeriksaan kasus tersebut, yang diperiksa adalah terdakwa subjek hukum orang (natural person) ${ }^{31}$ saja, sebagai pelaku tindak pidana yang secara melawan hukum telah melakukan perbuatan memperkaya diri sendiri atau orang lain atau suatu korporasi yang dapat merugikan keuangan negara atau perekonomian negara. Sementara itu korporasi an sich yang divonis sebagai pelaku tindak pidana oleh Mahkamah Agung tidak pernah diperiksa hingga di pengadilan, sehingga tidak ada kesempatan untuk dapat membela diri. Dalam putusan Pengadilan korporasi IM2 divonis Mahkamah Agung ${ }^{32}$ untuk membayar uang pengganti tersebut. Model putusan tindak pidana korporasi dalam kasus PT. IM2 ini, merupakan model pertanggungjawaban pidana korporasi "pengurus sebagai pembuat dan pengurus serta korporasi sebagai penanggungjawab", yaitu dengan dihukumnya subjek hukum Orang dengan Pidana Penjara selama 8 (delapan) tahun dan menjatuhkan Pidana Denda sebesar Rp 300.000.000,00 (tiga ratus juta rupiah), dan Subjek hukum korporasi PT. Indosat Mega Media (PT. IM2) dengan hukuman membayar uang pengganti sebesar Rp1.358.343.346.674,00. Penghukuman korporasi seharusnya dilakukan

\footnotetext{
${ }^{31}$ Terdakwa terdakwa subjek hukum orang (natural person): Indar Atmanto; Direktur Utama PT. IM2 (PT. Indosat Mega Media) sebagai orang yang melakukan atau turut serta melakukan dengan Kaizad B. Heerjee, Johnny Swandy Sjam, dan Harry Sasongko (lihat selanjutnya, Mahkamah Agung R.I, Supra catatan no. 25).

32 Id pada 2, Di dalam putusannya Mahkamah Agung memperbaiki amar Putusan Pengadilan Tipikor pada Pengadilan Tinggi Jakarta No. 33/PID/TPK/2013/PT.DKI. tanggal 12 Desember 2013 yang mengubah Putusan Pengadilan Tipikor pada PN Jakarta Pusat No. 01/Pid.Sus/TPK/2013/PN.Jkt.Pst tanggal 08 Juli 2013 sekedar mengenai pidana denda dan uang pengganti sehingga amar selengkapnya berbunyi sebagai berikut: 1) Menyatakan Terdakwa Indar Atmanto terbukti secara sah dan meyakinkan bersalah melakukan tindak pidana "KORUPSI DILAKUKAN SECARA BERSAMA-SAMA" ; 2) Menjatuhkan pidana terhadap Terdakwa tersebut dengan Pidana Penjara selama 8 (delapan) tahun dan menjatuhkan Pidana Denda sebesar Rp. 300.000.000,00 (tiga ratus juta rupiah) dan bila denda tersebut tidak dibayar diganti pidana kurungan selama 6 (enam) bulan ; 3) Menghukum PT. Indosat Mega Media (PT. IM2) membayar uang pengganti sebesar Rp1.358.343.346.674,00 (satu triliun tiga ratus lima puluh delapan miliar tiga ratus empat puluh tiga juta tiga ratus empat puluh enam ribu enam ratus tujuh puluh empat rupiah) dengan ketentuan apabila PT. IM2 tidak membayar uang pengganti tersebut paling lambat 1 (satu) bulan sesudah putusan mempunyai kekuatan hukum tetap, maka harta benda PT. IM2 disita oleh Jaksa dan dilelang untuk membayar uang pengganti tersebut.
} 
dengan terlebih dahulu memeriksa korporasi an sich sebagai tersangka oleh penyidik dan terdakwa dalam proses peradilan, dengan demikian PT. IM2 sebagai korporasi dapat diberi kesempatan untuk membela dirinya di pengadilan.

Kedua putusan perkara in concreto tersebut di atas adalah merupakan produk hukum pidana korporasi (materil) in abstracto yang anomali, karena telah memidana korporasi dengan hukum acara (formil) yang juga tidak sahih, sehingga layak untuk dikaji secara ilmiah, karena telah menciptakan ketidakpastian dan ketidakadilan baru yang mengakibatkan ketidaktertiban dalam aktifitas bisnis korporasi.

\section{Peranserta Advokat Sebagai Officium Nobile Dalam Membela Korporasi Terduga Pelaku Tindak Pidana Korporasi (Corporate Crimes)}

Makna Advokat sebagai sebuah istilah yang dapat ditemukan di dalam dunia sistem peradilan di Indonesia yang dahulu dikenal dengan berbagai peristilahan antara lain seperti pembela, penasehat hukum, pengacara, pokrol bambu, dan procereur, ${ }^{33}$ yang selanjutnya di dalam Undang-undang Advokat pengertiannya jauh lebih luas lagi yaitu orang yang berprofesi memberi jasa hukum, baik di dalam maupun di luar Pengadilan dengan suatu persyaratan tertentu.

Dengan berefleksi dari kesenjangan kedua perkara tersebut di atas, selain juga faktor penyidik, penuntut umum dan hakim, maka penyebab lainnya adalah faktor Advokat yang menangani perkara tersebut, tidak mampu untuk menampilkan fakta-fakta hukum dan unsur-unsur ilmiah suatu perbuatan pidana korporasi dalam perspektif corporate criminal legal science yang kian berkembang, direlasikan dengan aturan-aturan hukum yang dianggap relevan interpretasinya mendukung kepentingan kliennya selengkap mungkin dalam perkara tindak pidana korporasi yang sedang dihadapi. Seyogyanya kesemua faktor tersebut harus dikemas dalam suatu argumentasi yang objektif (ilmiah)

\footnotetext{
33 Timbo Mangaranap Sirait, Kongkritisasi Filosofi Profesi Officium Nobile Melalui Pendidikan Master Advokat 8 (Dewan Pimpinan Pusat Perkumpulan Advokat Indonesia, Jakarta, 2016).
} 
dan dibangun untuk menggiring pemikiran hakim dalam putusannya yang menciptakan kepastian hukum berkeadilan dari sudut pihak korporasi kliennya.

Hal itu selaras dengan pendapat B. Arief Sidharta yang mengatakan Pengacara (Advokat) adalah orang yang dalam proses peradilan bertugas untuk menampilkan fakta-fakta dari kejadian yang menimbulkan sengketa terkait selengkap mungkin, dan tentu saja yang mendukung kepentingan kliennya, termasuk aturan-aturan hukum yang dipandang relevan dan interpretasinya. Kesemuanya itu di kemas dalam suatu argumentasi yang rasional yang dibangun untuk mencapai suatu putusan hukum yang adil-manusiawi dari sudut pihak kliennya. ${ }^{34}$ Dalam konteks untuk menampilkan fakta-fakta tindak pidana korporasi dimaksud maka Advokat harus dapat meningkatkan pemahaman ilmiahnya tentang ilmu hukum pidana korporasi yang semakin bergeser.

Pergeseran nilai keilmuwan hukum corporate criminal legal science “...juga turut mempengaruhi cara kerja dan kinerja para Advokat di seluruh Indonesia akibat kelemahan dan keterbatasan ilmu pengetahuan (knowledge) advokatadvokat muda, serta ketidak-mampuan Organisasi Advokat membekali anggotanya untuk meningkatkan tata cara-kerja (knowhow) advokat dalam menegakkan hukum dan peraturan perundang-undangan mengikuti perkembangan ilmu pengetahuan dan tuntutan rasa keadilan masyarakat yang semakin meningkat. ${ }^{35}$

Advokat yang sejak dari semula ada merupakan sebuah profesi yang sarat dengan nilai-nilai idealis dan disebut dengan profesi mulia dan terhormat (officium nobile) karena perannya untuk memperjuangkan nilai-nilai hak asasi manusia dan kepentingan-kepentingan masyarakat dalam bidang hukum. Akan tetapi kini karena segala keterbatasan baik dari internal maupun eksternal, para praktisi advokat seringkali tidak mampu mengemban nilai-nilai officium nobile tersebut karena kurangnya kemampuan dan penghayatan advokat untuk memenuhi standar nilai-nilai mulia dan terhormat tersebut dalam jabatan

\footnotetext{
${ }^{34}$ B. Arief Sidharta, Etika dan Kode Etik Profesi Hukum, Volume 1 No. 1 Juni 2015, Jurnal Veritas et Justitia. 220, 238 (2015).

35 Timbo Mangaranap Sirait, supra no. 33 hlm. 4-5.
} 
profesinya, $^{36}$ termasuk upaya untuk meningkatkan kapabilitasnya dengan mengikuti pendidikan khusus tertentu agar memiliki keahlian khusus tertentu.

Padahal di dalam Pasal 3 ayat (2) Undang-undang Advokat telah diatur tentang perlunya pendidikan khusus hukum berkelanjutan (Continue Legal Education) yang mendasari agar Advokat dalam menjalankan prakteknya dapat mengkhususkan diri pada bidang tertentu, melalui peningkatan pendidikan untuk menghadapi tantangan sesuai dengan tuntutan perubahan kehidupan nasional, dan terutama dapat menjadi tuan rumah di negeri sendiri dalam persaingan global, bahkan dapat berkiprah secara internasional.

\section{Peranserta Organisasi Profesi Advokat Dalam Memberikan Pendidikan Hukum Berkelanjutan (Continue Legal Education) Bekerjasama Dengan Perguruan Tinggi Hukum}

Julian V. Roberts mengatakan “...society causes crime and offender (...) no society, no laws, no crime and no criminals. Once a society emerges, rules develop, and they are broken society must respond, otherwise the rules would lose their potency to affect behaviour. ${ }^{37}$ Dalam pandangan Julian, adanya masyarakatlah (korporasi/orang) penyebab adanya kejahatan dan pelakunya (...) tidak ada masyarakat, maka tidak ada hukum, tidak ada kejahatan dan tidak ada penjahat. Begitu sebuah masyarakat muncul, maka peraturan berkembang, dan mereka yang merusak masyarakat harus bereaksi, jika tidak, maka hukum akan kehilangan kemampuannya untuk mempengaruhi perilaku.

Oleh karena itulah hukum selalu tertatih-tatih mengikuti perkembangan sosial di masyarakat, dan membuat adanya kesenjangan antara dunia sollen dengan dunia sein, yang berimbas mempengaruhi dunia hukum in abstracto terhadap hukum in concreto. Maksudnya kesenjangan das sollen dengan das sein tersebut pasti akan berimbas kepada pengaturan hukum in abstracto dan penegakan hukum in concreto, di mana di dalamnya dunia profesi Advokat

\footnotetext{
36 Id.

${ }^{37}$ Julian V. Roberts, Criminal Justice, A Very Short Introduction, Oxford University Press, Oxford, OX2 6DP, United Kingdom, 2015, hlm 8.
} 
sebagai profesi yang mulia (nobile) juga akan turut tertatih-tatih dalam mengikuti perkembangan hukum yang mengakibatkan kendala memenuhi dan menegakkan terciptanya rasa kepastian hukum berkeadilan yang semakin berkembang di masyarakat.

Pembukaan Undang-Undang Dasar Negara Republik Indonesia tahun 1945 mengamanatkan Pemerintah Negara Indonesia yang melindungi segenap bangsa Indonesia dan seluruh tumpah darah Indonesia, dan untuk memajukan kesejahteraan umum, mencerdaskan kehidupan bangsa, dan ikut melaksanakan ketertiban dunia yang berdasarkan kemerdekaan, perdamaian abadi dan keadilan sosial, ${ }^{38}$ dan salah satu cara untuk mencapai cita-cita konstitusi tersebut adalah dengan meningkatkan kemampuan advokat sehingga benar-benar menjadi advokat yang cerdas, mulia dan terhormat (nobile) dalam menjalankan tugasnya (officium) melalui jalur pendidikan khusus berkelanjutan sehingga mampu berkompetisi di tingkat nasional maupun internasional.

Sebagai negara hukum berdasarkan Pancasila dan Undang-Undang Dasar Negara Republik Indonesia Tahun 1945, Negara bertujuan mewujudkan tata kehidupan bangsa yang sejahtera, aman, tenteram, tertib, dan berkeadilan, sangat memerlukan adanya advokat-advokat yang handal, karena terbukti secara historis profesi Advokat sebagai sebuah profesi terhormat atau yang disebut dengan Officium Nobile telah menjadi salah satu pilar dalam menegakkan suppremasi hukum dan hak asasi manusia sejak ribuan tahun yang lalu. ${ }^{39}$

Demikian juga halnya untuk menegakkan kekuasaan kehakiman yang bebas dari segala campur tangan dan pengaruh dari luar, sangat memerlukan profesi Advokat yang bebas, mandiri, dan bertanggung jawab, untuk terselenggaranya suatu peradilan yang jujur, adil, dan memiliki kepastian hukum bagi semua pencari keadilan dalam menegakkan hukum, kebenaran, keadilan, dan hak asasi manusia, dan Advokat sebagai profesi yang bebas, mandiri, dan

\footnotetext{
38 Undang-undang Nomor 20 Tahun 2003, Sistem Pendidikan Nasional. L.N.RI. Tahun 2003 No. 4301, Konsideran

39 Timbo Mangaranap Sirait, Supra no. 33, hlm. 19.
} 
bertanggung jawab dalam menegakkan hukum, perlu dijamin dan dilindungi oleh undang-undang demi terselenggaranya upaya penegakan supremasi hukum. ${ }^{40}$

Itu jugalah sebabnya, Undang-undang Dasar Negara Republik Indonesia Tahun 1945 mengamanatkan Pemerintah mengusahakan dan menyelenggarakan satu sistem pendidikan nasional, di mana di dalam konsideran Undang-undang sistem pendidikan nasional yang mengatakan negara harus mampu menjamin pemerataan kesempatan pendidikan, peningkatan mutu serta relevansi dan efisiensi manajemen pendidikan untuk menghadapi tantangan sesuai dengan tuntutan perubahan kehidupan lokal, nasional, dan global sehingga perlu dilakukan pembaharuan pendidikan secara terencana, terarah, dan berkesinambungan. ${ }^{41}$ Corporate criminal legal science adalah ilmu yang secara khusus mempelajari pilar-pilar hukum pidana korporasi menyangkut pilar Pidana dan Pemidanaan Korporasi (corporate criminal sentencing system), Pertanggungjawaban Pidana Korporasi (corporate criminal liability) dan Tindak Pidana Korporasi (corporate criminal act) yang dengan berkembangnya tuntutan rasa kepastian hukum berkeadilan ditambah dengan pilar Tujuan Pemidanaan Korporasi yang rumusannya sebagaimana tabel dibawah ini:

\section{Tabel: Tujuan, Pedoman dan Persyaratan Pemidanaan Korporasi Masa Depan (Ius Constituendum)}

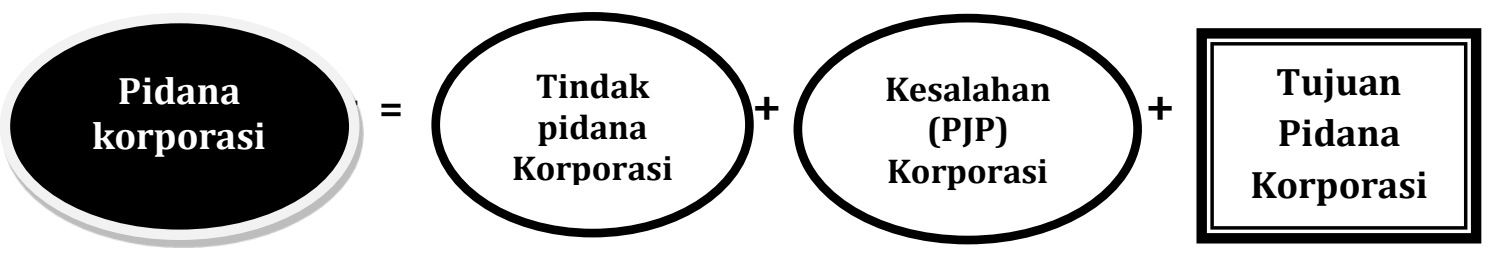

Tujuan Pemidanaan ini juga menjadi pilar baru dalam penegakan pertanggungjawaban pidana korporasi yang sangat penting posisinya, yang secara filosofis dan analogis dapat digambarkan "jangan sampai menangkap seekor ikan tetapi harus mematikan seluruh isi kolam". Hal ini menjadi sangat penting karena kedudukan korporasi sebagai kepanjangan tangan subjek hukum orang (natural

${ }^{40}$ Id, hlm. 19.

${ }^{41} \mathrm{Id}, \mathrm{hlm} .20$. 
person) juga berperan penting dalam lapangan ekonomi, menciptakan lapangan kerja dan berbagai pengaruh sosial lainnya yang positif.

Untuk itu peran serta organisasi advokat untuk memberikan pendidikan khusus hukum berkelanjutan (continue legal education) terhadap anggotanya dan khususnya terhadap calon (kandidat) advokat dengan bekerjasama dengan Perguruan Tinggi Hukum mutlak untuk dilakukan, demi menciptakan profesi Advokat yang "Ing Ngarso Sun Tulodo", "Ing Madyo Mbangun Karso", dan "Officium Nobile".

Oleh karena itu, dengan mencermati perkembangan dalam dunia profesi Advokat Indonesia yang sudah "Multy Bar" khusus advokat-advokat muda yang menjalankan tugasnya di seluruh Indonesia yang masih banyak memiliki keterbatasan knowledge dan knowhow dalam menjalankan profesinya, dan untuk mengharmoniskan perintah Pasal 3 ayat (2) Undang-undang Advokat dan Undang-undang No. 20 Tahun 2003 Tentang Sistem Pendidikan Nasional, maka Organisasi Profesi Advokat perlu berupaya aktif untuk memajukan dan meningkatkan profesi Advokat serta mengembalikan marwah Advokat sebagai jabatan yang Officium Nobile melalui program pendidikan khusus tambahan berupa knowledge dan knowhow khusus bidang advokat bekerjasama dengan Sekolah Tinggi Hukum atau Perguruan Tinggi Hukum.

Pengharmonisasian Undang-undang Advokat dan Undang-undang Sistem Pendidikan Nasional dalam rangka Pendidikan Profesi Advokat ini juga dalam rangka mengeksekusi Putusan Mahkamah Konstitusi Putusan MKRI Nomor 95/PUU-XIV/2016 yang memutuskan pendidikan Advokat harus dilaksanakan oleh Organisasi Advokat dengan menggandeng perguruan tinggi hukum atau sekolah tinggi hukum yang setidaknya sudah terakreditasi demi menjaga fungsi Advokat sebagai profesi yang bebas, mandiri, dan bertanggungjawab sebagaimana amanat perundang-undangan. Pendidikan Profesi Advokat dan Pendidikan khusus hukum berkelanjutan (continue legal education) harus diselenggarakan dan merupakan kerjasama wadah organisasi profesi advokat dengan perguruan tinggi. 


\section{Penutup}

Berdasarkan uraian di atas maka dapatlah disimpulkan; Pertama, bahwa secara universal sejarah perkembangan profesi Advokat telah mulai sejak masa Romawi dan kemudian diikuti dengan lahirnya korporasi (1243) yang awalnya tidak dapat dipidana (Societas delinquere non potest), kemudian berkembang menjadi dapat dipidana dan berlaku secara global. Kedua, bahwa perkembangan profesi Advokat dan korporasi sebagai subjek hukum pidana secara diakronis dimulai dari masa kolonialisme Hindia Belanda yang bergabung dalam Balie van Advocaten, kemudian setelah kemerdekaan menjadi multi bar di mana selanjutnya pada tahun 2003 menjadi single bar dibawah PERADI, dan terakhir melalui Surat Ketua Mahkamah Agung No. 73/KMA/HK.01/IX/ 2015 tertanggal 25 September 2015 kembali menjadi multi bar. Adapun perkembangan korporasi awalnya tidak dapat dipidana dalam Pasal 59 KUHP berobah secara bertolak belakang menjadi subjek hukum pidana melalui Undang-undang tahun 1951 hingga terbitnya PERMA No. 13/2016. Ketiga, bahwa terbitnya PERMA No. 13/2016 akan menjadi era baru penegakan tindak pidana korporasi, untuk mana peranserta advokat akan semakin meningkat memberi jasa hukum, dan oleh karena itu, seorang Advokat harus semakin meningkatkan kemampuannya membela kliennya, baik dalam bertindak sebagai perwakilan (representative) dari klien, sebagai konsultan, penasehat, pengacara, negosiator, eksaminator atas perkara klien. Keempat, bahwa kesenjangan hukum In Abstracto dan dampaknya terhadap pembelaan Advokat pada pidana korporasi In Concreto telah berimplikasi terhadap sedikitnya korporasi pelaku pidana yang dapat diminta pertanggungjawaban pidananya, dan sekaligus mengakibatkan timbulnya disparitas dalam putusan pengadilan yang melahirkan ketidakadilan baru. Kelima, bahwa merujuk pada makna terma Advokat sebagai pemberi jasa hukum didalam maupun diluar pengadilan, maka Advokat sebagai profesi yang Officium Nobile dalam membela korporasi terduga pelaku tindak pidana Korporasi (Corporate Crimes), seyogyanya harus mampu mengkemas argumentasi hukum yang objektif (ilmiah) dalam perspektif corporate criminal legal science yang kian berkembang, kemudian direlasikan dengan aturan-aturan hukum yang dianggap relevan, dengan membekali diri 
(melalui Organisasi Advokat) guna meningkatkan tata cara-kerja (knowhow) keahlian khusus tertentu melalui pendidikan khusus hukum berkelanjutan (Continue Legal Education). Keenam, bahwa sebagaimana Putusan Mahkamah Konstitusi R.I. No. 95/PUU-XIV/2016, Undang-undang Advokat, Undang-undang Perguruan Tinggi, dan Undang-undang Sistem Pendidikan Nasional, maka peranserta Organisasi Profesi Advokat sangat diharapkan dapat meningkatkan mutu dan meng-uptodate ilmu hukum Advokat anggotanya guna memberikan Continue Legal Education baik dalam bidang hukum pidana korporasi maupun bidang-bidang hukum lainnya secara terkini dengan bekerjasama dengan perguruan tinggi hukum.

\section{Daftar Pustaka}

\section{Buku:}

Abdussalam \& DPM Sitompul, Sistem Peradilan Pidana, Restu Agung, Jakarta, 2007.

Bernard Arief Sidharta, et.al. Pengemban Hukum Teoritis, Refleksi Atas Konstellasi Disiplin Hukum, Logoz Publishing, Bandung, 2014.

Binzaid Kadafi, et. al., Pembentukan Organisasi Advokat Indonesia: Keharusan atau Tantangan?, Pusat Studi Hukum \& Kebijakan Indonesia atas kerjasama dengan The Asia Foundation, Jakarta, 2004.

Brodowski, Dominik, et.al., Requlating Corporate Criminal Liability, Springer, Switzerland, 2014.

Djoko Prakoso, Kedudukan Justisiabel di dalam KUHAP, Ghalia Indonesia, Jakarta, 1986.

Forsyth, William, History of Lawyers, Ancient and Modern, Estes \& Lauriat, Boston, Washington Street, 1875.

Gillers, Stephen, et.al., Regulation of Lawyers, Wolter Kluwer, New York, 2017.

Moelyatno, Asas-asas Hukum Pidana, Rineka Cipta, Edisi Revisi, Jakarta, 2008.

Roberts, Julian V., Criminal Justice, A Very Short Introduction, Oxford University Press, Oxford, OX2 6DP, United Kingdom, 2015.

Timbo Mangaranap Sirait, Kongkritisasi Filosofi Profesi Officium Nobile Melalui Pendidikan Master Advokat, Dewan Pimpinan Pusat Perkumpulan Advokat Indonesia, Jakarta, 2016. 


\section{Jurnal}

B. Arief Sidharta, Etika dan Kode Etik Profesi Hukum, Volume 1 No. 1 Juni 2015, Jurnal Veritas et Justitia, 2015.

Timbo Mangaranap Sirait, Urgensi Perluasan Pertanggungjawaban Pidana Korporasi Sebagai Manifestasi Pengejawantahan Konstitusi, Jurnal Konstitusi, Mahkamah Konstitusi R.I., Volume 13 Nomor 3, September 2016.

\section{Makalah}

Dwidja Priyatno, Seminar Nasional, Menjerat Korporasi Dalam Pertanggungjawaban Hukum, Dalam Rangka Peringatan HUT IKAHI ke-64, IKAHI, Hotel Mercure Ancol Jakarta, 21 Maret 2017 (tidak dipublikasi).

\section{Internet}

hukumonline, "UU ini kerap dipakai aparat dalam Menjerat Korporasi", tersedia di: m.hukumonline.com/berita/baca/lt588548020bfc0/uu-ini-kerap-dipakai -aparat-dalam-menjerat-korporasi.

\section{Peraturan Perundang-undangan}

Undang-undang R.I. No. 1 Tahun 1946 Jo. Undang-undang R.I. No. 73 Tahun 1958 Tentang Menyatakan Berlakunya UU No. 1 Tahun 1946 R.I. Tentang Peraturan Hukum Pidana Untuk Seluruh Wilayah R.I. dan Mengubah Kitab Undang-undang Hukum Pidana L.N.R.I. 1958 No. 127 Tambahan L.N.R.I. No. 1660.

Undang-undang R.I., No. 1 Tahun 1953, Penetapan Undang-undang Darurat Tentang Penimbunan Barang Sebagai Undang-undang, L.N.R.I. No. 4 telah menetapkan korporasi sebagai subjek hukum pidana, dan 4 tahun kemudian ditindaklanjuti lagi dengan Undang-undang Darurat No 7 Tahun 1955, Pengusutan, Penuntutan dan Peradilan Tindak Pidana Ekonomi, L.N.R.I. Tahun 1955 No. 27.

Undang-undang R.I., No. 18 Tahun 2003, Advokat, L.N.R.I. Tahun 2003 No. 49.

Undang-undang Nomor 20 Tahun 2003, Sistem Pendidikan Nasional. L.N.RI. Tahun 2003 No. 4301.

Undang-Undang No. 32 tahun 2009, Perlindungan dan Pengelolaan Lingkungan Hidup, L.N.R.I. Tahun 2009 No. 140.

Peraturan Mahkamah Agung R.I., No. 13 Tahun 2016, Tata Cara Penanganan Perkara Tindak Pidana Oleh Korporasi, L.N.R.I. Tahun 2016 No. 2058.

\section{Putusan Pengadilan}

Mahkamah Agung R.I., Putusan Nomor 787/ K/ Pid. Sus/ 2014.

Mahkamah Konstitusi R.I., Putusan Nomor 95/PUU-XIV/2016

\section{Lain-lain:}

Kamus Bahasa Indonesia, Pusat Perbukuan, Departemen Pendidikan Nasional, Jakarta, (2008). 